\title{
AN INTERPOLATION OF JENSEN'S INEQUALITY AND ITS CONVERSES WITH APPLICATIONS TO QUASI-ARITHMETIC MEAN INEQUALITIES
}

\section{JADRANKA MićIĆ HOT AND YUKI SEO}

Abstract. In this paper, we show an interpolation of Davis-Choi-Jensen operator inequality and the converse inequality for Hilbert space operators. As applications, we obtain an interpolation of quasi-arithmetic mean inequalities and the converse inequalities.

Mathematics subject classification (2010): Primary 47A63, secondary 47A64.

Keywords and phrases: Jensen's inequality, converse of Jensen's inequality, positive linear mapping, convex function, quasi-arithmetic mean.

\section{REFERENCES}

[1] Y.J. Cho, M. Matić AND J. PeČARIĆ, Two mappings in connection to Jensen's inequality, Panamerican Math. J., 12(2002), 43-50.

[2] S.S. DRAGOMIR, Hermite-Hadamard's type inequalities for operator convex functions, Appl. Math. Comput. 218 (2011), 766-772.

[3] S.S. DRAGOMIR, Hermite-Hadamard's type inequalities for convex functions of selfadjoint operators in Hilbert spaces, Linear Algebra Appl. 436 (2012), 1503-1515.

[4] T. FujiI, J. Mićić Hot, J. PeČarić AND Y. SEO, Recent Developments of Mond-Pečarić Method in Operator Inequalities, Monographs in Inequalities 4, Element, Zagreb, 2012.

[5] L. LAWSON AND Y. LIM, Karcher means and Karcher equations of positive definite operators, Trans. Amer. Math. Soc., Series B, 1(2014), 1-22.

[6] J. MiĆIĆ AND J. PEČARIĆ, Some mappings related to Levinson's inequality for Hilbert space operators, Filomat 31 (2017), 1995-2009.

[7] J. MićIĆ, J. PEČARIĆ AND J. PERIĆ, Refined converses of Jensen's inequality for operators, J. Inequal. Appl. 2013:353 (2013) 1-20.

[8] J. Mićić Hot And Y. SEO, An interpolation of Jensen's inequality and its applications to mean inequalities, J. Math. Inequal. 12 (2018), 303-313. 